\title{
SUSTAINABLE GROUNDWATER MANAGEMENT IN ROLLING TERRAIN AROUND THE SACRED KATAS RAJ TEMPLES, SALT RANGE, PAKISTAN UNDER CLIMATE CHANGE AND INDUSTRIAL STRESS
}

\author{
Muhammad Hasan ${ }^{1}$, Noor Khan ${ }^{2}$, Habib Rehman ${ }^{2}$, and Shahid Ali ${ }^{3}$ \\ ${ }^{1}$ Mines \& Minerals Department \\ ${ }^{2}$ University of Engineering and Technology \\ ${ }^{3}$ National University of Computer \& Emerging Sciences, Lahore, Pakistan
}

September 28, 2020

\begin{abstract}
Ancient Katas Raj Temples, the legacy for humanity, is inscribed in the UNESCO world heritage tentative list. The most vital object related to this valuable heritage is the sacred natural water pond located amidst the temples of "Katas" in Pakistan. Hindus believe that the pond was originated by the tear shed of Lord Shiva on the death of his wife some 4,000 years ago. The water pond is currently threatened due to the lowering of the water table caused by the over-abstraction of groundwater for agriculture, domestic and industrial usage in the last decade, arising to the Hindu community's distress. Therefore, sustainable groundwater management is paramount to safeguard the pond. This study thus applied the Visual MODFLOW model using topographical, metrological, and hydrological data of the region to forecast the groundwater fluctuation in the next 10 years (2021-2030) based on the current abstraction scenario and anticipated scenarios, besides the application of Managed Aquifer Recharge (MAR) methods. The results of mass balance and groundwater depletion depict that the current abstraction rate is $40 \%$ more than the natural recharge which is not sustainable, resulting in an average drawdown of $0.50 \mathrm{~m} / \mathrm{year}$ around the sacred Katas Raj Temples. The expected future economic development \& agricultural growth predicted even the worst scenario. The open surface ponding was found to be an optimal method of MAR that overcomes $60 \%$ of the water budget deficit. Based on the results of the study, a sustainable water management plan has been recommended for groundwater resource development of the area to rehabilitate the pond.
\end{abstract}

\section{INTRODUCTION}

A cluster of ancient temples known as Katas Raj is located in the Choa Saiden Shah (Study Area), a town of the Salt Range, Punjab, Pakistan. The Katas Raj Temples antedate the birth of Jesus by hundreds of years (Ali, 2015). Scientist Alberuni attempted to measure the circumference of the earth at the place of Katas Raj (Shahab, 2019). The Katas Raj complex is a sanctified place in the Hindu religion especially the sacred pond that has different myths regarding its formation. Hindus believe that all the sins are washed out after taking a bath in the pond. According to the book of Rig Veda, a small stream having a depth of 300 yards exists just beneath the pond (Shahab, 2019). Apparently, the pond is filled naturally from the series of springs and artesian aquifer since its creation. The pond occupies an area of 14960 sq. ft., with a maximum depth of 20 feet. Until 2007, there was no shortage of water in the pond but after industry development and agriculture growth, its water level started declining, ultimately drying-up in 2017. The agriculture sector is 
the major user of groundwater in the study area beside the domestic water supply. The cement industry also prefers to use groundwater for the cooling process due to its local availability and acceptable quality.

The concern of the Hindu community is that the Government of Pakistan does not take care of the pond (Ali, 2015). No doubt the Government of Punjab took initiatives in the renovation of the temples but unfortunately no concrete steps were taken to preserve the pond due to lack of knowledge about its groundwater system. The groundwater levels are expected to face even worse conditions because the cement industry is going to further expand in the Salt Range to meet the increasing demand for cement due to China Pakistan Economic Corridor (CPEC) projects and future economic development of the country. Given the extent of groundwater resource depletion during the last 10 years, water management is necessary to ensure the sustainable use of water in the Salt Range which needs a comprehensive hydrogeological/hydrometric study. (National Engineering Services of Pakistan, "Delineating Negative and Positive Mining Areas for the Installation of Cement Plants in the Salt Range",unpublished report, 2018). In past, no appreciable studies were carried out for groundwater analysis of the study area to suggest measures to mitigate the effect of climate change and industrial stress. However, recently, a study was carried out to assess the impact of water abstraction on the aquifer of the Kahoon Valley, Choa Saiden Shah based on limited geological and hydrological data without creating any groundwater flow model. This study concluded that the water table has declined by $4.8 \mathrm{~m}$ on average in the whole valley in 08 years between 2004 and 2012 proposing numerical computer modelling to opt optimal method for artificial recharge of the aquifer of the Kahoon Valley for sustainable water resource development (Dr. A.D Khan, Oriental Engineering Services, Lahore, Pakistan, "Impact Assessment of Groundwater Pumping on Kahoon Valley Aquifer", unpublished report, 2012).

Already Pakistan uses groundwater resources to the maximum limits of withdrawal causing significant drawdown of the water table in different parts of the country (Young et al., 2019). For instance, the Rachna Doab, command area of Lower Chenab Canal (LCC) in west Punjab Province is currently threatened due to the significant drawdown of the water table which would reach a maximum of $14 \mathrm{~m}$ till 2030 based on current abstraction against the existing recharge rate, recommending sustainable water management (Shakoor et al., 2018). Similarly, the water table in Mithawan spate irrigated area of D.G. Khan, Pakistan is expected to deplete up to $2.85 \mathrm{~m} / 10$ years in the period from 2014 to 2024 based on current abstraction which may be stopped by maximum use of spate water/ hill torrent for irrigation and reduce the reliance on groundwater (Ahmad, Arshad, Iqbal, Waqas, \& Awais, 2017).

Groundwater abstraction is $33 \%$ of total water withdrawals worldwide, consequently, most of the aquifers in arid and semi-arid zones that rely on groundwater are experiencing rapid drawdown of groundwater (Famiglietti, 2014). The global groundwater depletion has increased from 126 to $283 \mathrm{~km}^{3}$ within 40 years from 1960 to 2000 in sub-humid to arid zone(Wada et al., 2010). This depletion rate has increased significantly since 1950, with a maximum average rate of $145 \mathrm{Km}^{3} /$ year which is equivalent to a $0.40 \mathrm{~mm} /$ year rise in see-level during the period 2001-2008 (Konikow, 2011).

A few other archaeological/sacred places are also facing a similar issue as that of Katas Raj sacred pond. The water tanks/ponds of Mylapore and Thirupporur temples located in the city of Madras, India had dried out in the past decade due to rapid urbanization and continuous groundwater abstraction. Due to urbanization $90 \%$ area around the temple tanks has become paved causing no recharge to the aquifer, therefore, these tanks can only be fed artificially by rainwater harvesting through storm drains covering all the catchment areas which originally contributed to recharging the tanks (Ganesan, 2008). The artificial recharge of an aquifer is termed as Managed Aquifer Recharge (MAR). A variety of methods are used for MAR such as streambed channel modifications, infiltration galleries, recharge wells, and runoff harvesting (Dillon et al., 2019). The runoff harvesting is an efficient method for aquifer recharge in arid areas and cost-effective as compared to other methods of MAR (Hashemi, Berndtsson, \& Persson, 2015). MAR describes the global recharge of the aquifer for environmental protection and the quality of groundwater (Sheng \& Zhao, 2015). MAR is an important water management strategy to balance the water-stressed groundwater system. The other purpose of MAR is to overcome the seawater intrusion and land subsidence (Bouwer, 2002). MAR requires permeable soils for surface infiltration and in the case of impermeable soils, the aquifer is recharged 
through vertical injection by digging trenches or wells in the vadose zone (Bouwer, 2002). The researchers emphasize MAR methods for sustainable water management keeping in view the future demand for water, global warming, and climate change.

Sustainable groundwater development needs to be exercised for the recovery of the environment and groundwater quality. Therefore, the current study is an effort to analyse the groundwater regime of the study area under different development scenarios besides the application of the MAR approach using state of the art groundwater modelling techniques to select a suitable strategy for sustainable groundwater management to protect the sacred pond.

\section{Description of the Study Area}

Salt Range, the mining hub in Punjab, Pakistan, is a series of hills having length of $250 \mathrm{~km}$ and is $10 \mathrm{~km}$ wide. The range contains deposits of salt \& coal. Cement factories are the main industrial sector in this area having large production of Portland cement. The study area is a small valley that lies between $32^{\circ} 40^{\prime} 0$ ' $\mathrm{N}$ latitude and $72^{\circ} 42^{\prime} 0$ 'E longitude spread in $175 \mathrm{~km}^{2}$ in the Salt Range. The ancient Katas Raj Temples are located in the northern part of the Salt Range in the Potohar Plateau region of Province Punjab, at latitude $32^{\circ} 43^{\prime} 26.47^{\prime \prime} \mathrm{N}$ and longitude $72^{\circ} 57^{\prime} 5.96^{\prime \prime} \mathrm{E}$ as shown in Figure.1 .

The topography of the area plays an important role in the groundwater flow pattern. Generally, the groundwater follows surface topography flowing from a higher elevation recharge zone to a lower elevation discharge zone. The Digital Elevation Model (DEM 30 m SRTM) of the study area was downloaded from U.S Geological Survey (USGS) Earth Explorer Portal as shown in Figure.2 . The surface elevation varies between $598 \mathrm{~m}$ to $979 \mathrm{~m}$ above Mean Sea Level (MSL).

\section{DATA \& METHODS}

The requisite data required for the study such as soil flow properties, groundwater abstraction, rainfall, geological formation, and observation wells was obtained from concerned Government Departments \& Agencies. The initial groundwater heads were taken from 32 boreholes drilled in 2011 by the 'Punjab Mines \& Mineral Department' for mining purposes. These boreholes also provide information regarding subsurface geology of the soil layers. The formations exposed near Katas and its vicinity indicate the presence of alluvium clay mixed with sand gravel having a thickness of $05 \mathrm{~m}$ from the top surface. The sand/gravel exists from 05 to $100 \mathrm{~m}$ and beyond $100 \mathrm{~m}$ shale is encountered. The rainfall data for the last 10 years (2010-2020) was used for model development. One hundred forty-nine agriculture tube wells abstracting $59,174 \mathrm{~m}^{3} /$ day, 15 domestic water supply schemes abstracting $6,242 \mathrm{~m}^{3}$ /day, and 27 industrial tube wells abstracting 10,284 $\mathrm{m}^{3} /$ day are operational in the study area.

\section{Groundwater Flow Model Development}

Across the globe, there are many groundwater simulation platforms/ flow models such as AQUA3D, FLOWPATH, GFLOW, GMS, PROCESSING MODFLOW (PMWIN), SEAWAT, MODPATH, etc., but MODFLOW is the most commonly used three-dimensional numerical groundwater flow model developed originally by USGS (McDonald \& Harbaugh, 1988). MODFLOW is based on partial differential finite difference schemes that simulate three-dimensional groundwater flow for the solution of the governing mathematical flow equations (Harbaugh, Banta, Hill, \& McDonald, 2000). It has more advantages like facilities for easy data input, compatibility with other software, availability of source code, output visualization in two \& three-dimensions, worldwide experience, and relatively low price (Kumar, 2002). The finite differencebased MODFLOW uses a three-dimensional flow equation (Equation 1) combining with Darcy's Law and the principle of conservation of mass (Kumar, 2013). 


$$
\underline{\frac{\partial}{\partial x}\left\{K \mathrm{xx} \frac{\partial h}{\partial x}\right\}+\frac{\partial}{\partial y}\left\{K \mathrm{yy} \frac{\partial h}{\partial y}\right\}+\frac{\partial}{\partial z}\left\{K \mathrm{zz} \frac{\partial h}{\partial z}\right\}-W=S s \frac{\partial h}{\partial t} \quad \text { (1) }}
$$

Where:

Kxx: Hydraulic conductivity along $\mathrm{X}$ axis

Kyy: Hydraulic conductivity along Y axis

Kzz: Hydraulic conductivity along $\mathrm{Z}$ axis

H: Potentiometric head

W: Volumetric flux

Ss: Specific storage of the material

T: Time step

For the current study, the 'Visual MODFLOW Premium 2011.1 was used to develop a model for simulation of the groundwater regime of the study area. Two layers' groundwater Visual MODFLOW model was developed with transient flow condition having a $650 \mathrm{~m}$ x $650 \mathrm{~m}$ grid size. The data of 191 pumping wells for the period 2011- 2020 and 03 observation wells were assigned to the model.

\section{Flow Properties}

A groundwater flow model requires different hydrogeological properties like hydraulic conductivity, specific storage, porosity, and specific yield to simulate the hydrogeological process. The lithology/geology of the study area was observed from borehole logs \& reports of the Geological Survey of Pakistan (Dr. Firdous, Geological Survey of Pakistan, "Preliminary Report on the Geology of Sri Katas Raj and Adjoining Areas" , 2020). Some more literature (Subramanya, 2007), (Maidment, 1993), (Batu, 1998) was also reviewed for reference values of soil properties. The values of hydraulic conductivity of the soils were determined by performing slug tests that lie within the referenced values. The different values of soil flow properties were assigned to the model to calibrate the model by hit \& trail method to get the calibrated values within permissible limits as shown in Table 1 .

\section{Boundary Conditions}

The boundary conditions represent the flow exchange between the model and the external hydrological system (Hariharan \& Shankar, 2017). Boundary conditions are critical in groundwater modelling to get a close result to the field situation (Kumar, 2013). The accuracy of the results depends on field testing especially borehole data and pumping test. The accuracy of the results directly correlates with the accuracy of the boundary condition. Following boundary conditions were assigned to the model based on field conditions.

\section{Aquifer Recharge}

The aquifer recharge depends on hydraulic conductivity and storage of the upper layer. Surface water enters the groundwater system from the ground surface. Therefore, Visual MODFLOW allows to assign recharge values to the uppermost layer only in layer view mode (Hydrogeologic, 2015). For the current study, $15 \%$ of annual rainfall was assigned to the model (Dr. A.D Khan, Oriental Engineering Services, Lahore, Pakistan,Impact Assessment of Groundwater Pumping on Kahoon Valley Aquifer , unpublished report, 2012). 


\section{General Head Boundary Condition (GHBC)}

The purpose of GHBC is to avoid unnecessary outspreading of the model domain (Hydrogeologic, 2015). It is used to contain the model domain within the boundary of the area under consideration. Kallar Kahar Lake is present at a distance of $05 \mathrm{~km}$ from the western boundary of the study area, therefore, it was assigned as GHBC on the respective side of the model.

\section{No Flow Boundary Condition}

The study area is a semi-closed valley bounded with deep impermeable rocks on three sides restricting subsurface flow to the aquifer from outside the valley or vice versa. The source of the sacred pond may be the fractured limestone a confined/artesian aquifer containing groundwater under positive pressure (Dr. A.D Khan, Oriental Engineering Services, Lahore, Pakistan, Impact Assessment of Groundwater Pumping on Kahoon Valley Aquifer, unpublished report, 2012). The recharge in this area, therefore, is mainly from precipitation. Since there is no subsurface inflow/outflow from these sides hence "No Flow Boundary Condition" was assigned to the model on respective sides as shown in Figure. 3. The Lake boundary condition was assigned in the MAR scenario only.

\section{Model Calibration \& Sensitivity Analysis}

The model was calibrated for three observation wells for the years 2012, 2013, 2016, and 2020. Various parameters were adjusted such as hydraulic conductivity, specific yield, porosity, and specific storage to calibrate the model by hit \& trail method. The simulated values of observation wells lie within the $95 \%$ confidence interval as shown inFigure. 4 and simulated results of observation wells are shown in Figure. 5 . The standard error of the mean is $0.275 \mathrm{~m}$ whereas the correlation coefficient is 0.998 .

A sensitivity analysis is a process in which the input parameters are varied within the allowable range to observe a relative change in the model response. For the current study, different input parameters were varied to observe the model calibration response. Hydraulic conductivity was varied within allowable limits to observe its impact on the calibrated results of the model. It was observed that by varying hydraulic conductivity, the calibrated results of the model were disturbed manifold as shown in Table 2 .

\section{RESULTS \& DISCUSSION}

The calibrated model was run for 20 years period i.e. 10 years historic simulation (2011-2020) and 10 years prediction period (2021-2030) based on current/ actual abstraction scenario and different anticipated scenarios. The past 10 years (2011-2020) rainfall data was used for historic simulation and the same trend was used for the prediction period with one-year stress period.

\section{Scenario 1 (Current/Actual Pumping)}

In scenario 01, actual abstraction was put in historic simulation and the same rate was used for the prediction period without any change.Figure. 6 shows the simulated results for 10 years historic period for the year 2020 with a maximum drawdown of 11 to $15 \mathrm{~m}$ in the industrial area and 5 to $7 \mathrm{~m}$ in the agriculture area. Figure. 7 depicts the simulated results after 20 years for the year 2030 observing anticipated drawdown up to $20 \mathrm{~m}$ in the industrial area and up to $10 \mathrm{~m}$ in the agriculture area. A negative drawdown of 2 to $4 \mathrm{~m}$ has also been observed in some areas where there is less or no groundwater abstraction. The average drawdown was calculated for the historic period and the prediction period. An average drawdown of $05 \mathrm{~m} @ 0.5 \mathrm{~m} /$ year occurred in the 10 years historic period (2011-2020) and the same is anticipated in the prediction period (2021-2030) with the current abstraction rate. 


\section{Scenario 2 (Projected Abstraction)}

In scenario 02, the actual groundwater abstraction was assigned to the model in the historic period however, a projected abstraction was used in the prediction period based on the cement industry expansion \& population growth rate. The regression analysis between population growth rate and abstraction rate (domestic + agriculture) was made based on historic data. Based on the analysis, the current abstraction (domestic + agriculture) was projected @1.3\% per annum in the prediction period and the current industrial abstraction was projected @10\% per annum keeping in view the water demand for future expansion of the cement industry. The increase in industrial abstraction in the prediction period is a hypothesis, based on the expected installation of cement factories in the study area.

Figure. 8 represents the simulated results after 20 years for the year 2030 showing maximum drawdown up to $24 \mathrm{~m}$ in the industrial area and up to $12 \mathrm{~m}$ in the agriculture area. The simulated results depict that the projected abstraction in the prediction period resulted in an even worse scenario. The average drawdown was calculated for the historic period and the prediction period. Anaverage drawdown of $05 m$ @ $0.5 \mathrm{~m} /$ year occurred in the 10 years historic period (2011-2020) and an average drawdown of $7.4 \mathrm{~m} @ 0.74 \mathrm{~m} /$ year is anticipated in the prediction period (2021-2030)

\section{Scenario 03 \& 04 (Controlled Pumping)}

After a number of trial-runs, with various percentages of controlled (reduced) pumping, it has been observed that a 20 to $40 \%$ reduction in current abstraction leads the groundwater system to the equilibrium state. From these trial-runs, two scenarios of controlled pumping i.e. $20 \%$ and $40 \%$ reduction in current abstraction are illustrated here. The current/actual groundwater abstraction was taken in the historic period but reduced by $20 \% \& 40 \%$ in the prediction period in scenario 03 and 04 respectively. Figure. 9 represents the simulated results of scenario 03, after 20 years for the year 2030 showing maximum drawdown up to $17 \mathrm{~m}$ in the industrial area and up to $7 \mathrm{~m}$ in the agriculture area. The average drawdown was calculated for the historic period and the prediction period. An average drawdown of $05 \mathrm{~m} @ 0.5 \mathrm{~m} /$ year occurred in the 10 years historic period (2011-2020) and an average drawdown of $2.1 \mathrm{~m} @ 0.21 \mathrm{~m} /$ year is anticipated in the prediction period (2021-2030).

Similarly, Figure. 10 represents the simulated results of scenario 04, after 20 years for the year 2030 showing maximum drawdown up to $15 \mathrm{~m}$ in the industrial area and up to $05 \mathrm{~m}$ in the agriculture area. The simulated results of scenario 04 for the year 2030 are almost identical to simulated results of scenario 01 for the year 2020 showing no change in the prediction period. The average drawdown was calculated for the historic period and the prediction period. An average drawdown is $05 \mathrm{~m} @ 0.5 \mathrm{~m}$ /year occurred in the 10 years historic period (2011-2020) and an average of zero drawdown is anticipated in the prediction period (2021-2030)

\section{Scenario 5, (Managed Aquifer Recharge)}

Due to high altitude and rolling terrain the canal irrigation system is not present in the study area. Therefore, groundwater is the main source of agriculture. The impact of River Jhelum was assessed by assigning GHBC to the model, but no effect was observed on the simulated results due to the significant difference in elevation of the river and the study area. The recharge in this area is mainly from precipitation. The recharge to groundwater generally varies from 15 to $20 \%$ of the total precipitation depending upon the soil, land use/land cover, and intensity of the precipitation (Augustyn, 2020). The annual precipitation in the study area is averaged at $626 \mathrm{~mm}$ in the last 10 years (2009 to 2019). Therefore, rainwater harvesting through open surface ponding is the most feasible method of MAR. The recharge ponds are the common approach for MAR that involves surface infiltration through ponds to induce rainwater into the aquifer (Grau-Martínez et al., 2018).

The watershed of the study area was delineated using ArcGIS as shown inFigure. 11. The catchment area of the watershed is about $70 \mathrm{~km}^{2}$ which contributes $32,789 \mathrm{~m}^{3} /$ day inflow caused by annual precipitation. 
MAR technique was applied by assigning 03 ponds/lakes of size $1950 \mathrm{~m}$ x $650 \mathrm{~m} \mathrm{x} 3 \mathrm{~m}$ each to the models on appropriate places to accommodate flood runoff in the prediction period. Figure.12 represents the simulated results of scenario 05 , after 20 years for the year 2030 showing maximum drawdown up to $13 \mathrm{~m}$ in the industrial area and up to $7 \mathrm{~m}$ in the agriculture area. The average drawdown was calculated for the historic period and the prediction period. An average drawdown of $05 \mathrm{~m} @ 0.5 \mathrm{~m} /$ year occurred in the 10 years historic period (2011-2020) and an average drawdown of $1.6 \mathrm{~m} @ 0.16 \mathrm{~m} /$ year is anticipated in the prediction period (2021-2030) in scenario 5 .

The mass budget of the groundwater system of the study area represents a natural aquifer recharge of 53,016 $\mathrm{m}^{3}$ /day against the total abstraction of $75,283 \mathrm{~m}^{3}$ /day under scenario 01 and the pond/lakes contribute 13,333 $\mathrm{m}^{3}$ /day infiltration to the aquifer under scenario 05 as shown in Figure 13 .

Figure. 14 represents the comparison of the scenarios analysis. Up to the year 2020, all scenarios give the same trend representing groundwater depletion in the past which is defiantly a non-favourable condition. Any increase in current abstraction in case of agriculture / industrial growth would cause extra pressure on groundwater resources as evident from the results of scenario 02. Scenario 04 is the most favourable scenario that can bring back the groundwater system to equilibrium as there is negligible drawdown in the prediction period with a $40 \%$ reduction in current abstraction. Even the $20 \%$ reduction in current abstraction can reduce the drawdown significantly. The MAR through open surface ponding would be more helpful in aquifer recharge as it contributes to the aquifer recharge significantly.

Figure.15 shows the flow path of simulated groundwater from the low abstraction zone (agriculture area) to the intense abstraction zone (industrial area). The sacred pond is located near the boundary of the industrial area and inward flow direction toward the industrial area influences the natural flow path of groundwater recharging the pond.

\section{CONCLUSIONS}

The objective of the research was to analyse the groundwater regime of the study area in the perspective of groundwater abstraction being made by different stakeholders besides the application of MAR. The requisite data required for the model development was obtained from concerned government departments. Visual MODFLOW groundwater model was developed based on metrological, geological, geotechnical, hydrological, and abstraction data of the study area. The model was calibrated using sensitivity analysis through the iterative process. The scenario modelling was carried out for groundwater analysis of the study area for different scenarios viz current abstraction scenario, projected abstraction scenario, and reduced abstraction scenarios. Besides scenario modelling, different methods of MAR were considered to suggest a viable and feasible method for sustainable groundwater management.

Based on the simulated results and discussion, it has been established that an average $05 \mathrm{~m}$ drawdown occurred for the last decade and the groundwater flow path depicts that the cement factories installed at upstream of the sacred pond, influence the groundwater flow path, recharging the holy pond. Therefore, the over-abstraction from 2011 to 2020 around the close vicinity of the Katas Raj Temples is the main cause of drying out of the sacred pond.

The mass budget depicts that the current abstraction rate is $40 \%$ more than the natural recharge of the aquifer resulting in the rapid drawdown of the groundwater. Therefore, the current abstraction is unsustainable, which if left uncontrolled, would further lead to an average 05 meters of groundwater depletion by the year 2030 causing severe environmental hazards to the study area.

The projected abstraction in the case of industrial development and agriculture growth predicted the worst scenario of an average $7.4 \mathrm{~m}$ of groundwater depletion by the year 2030. Therefore, alternative sources of water need to be explored to meet future water demand. However, a $40 \%$ reduction in the current abstraction 
rate can bring the groundwater use to a safe abstraction resulting in sustainable water management in the future.

The results of MAR depict that the open surface ponding is a more feasible and economical method that would contribute to the aquifer recharge significantly as it overcomes the $60 \%$ groundwater budget deficit.

\section{Recommendations}

The sustainable water management of the study area can be achieved by adopting the following recommendations:

- The open surface ponds should be constructed on appropriate places to accommodate the surface runoff for infiltration to recharge the aquifer which would recover $60 \%$ of the groundwater budget deficit.

- The air cooling system should be installed in existing cement plants to reduce the reliance on groundwater up to $50 \%$ of its current abstraction which would balance $22 \%$ of the water budget deficit.

- The remaining $18 \%$ water budget deficit can be catered by switching current flood irrigation systems to sprinkling or drip irrigation techniques in some feasible areas to reduce the crop water requirement.

- The cement industry should abstract groundwater from the low abstraction zone downstream of the sacred water pond within latitude $32^{\circ} 42^{\prime} 26.47^{\prime \prime} \mathrm{N}$ and longitude $72^{\circ} 58^{\prime} 5.96^{\prime \prime} \mathrm{E}$ to avoid localized drawdown which would helpful in rehabilitation of the sacred pond on a long-term basis. The groundwater abstraction within a $4 \mathrm{~km}$ radius around the sacred pond should also be restricted.

- River Jhelum should be utilized to meet the future demand for water for the proposed cement industry and agriculture needs to reduce the reliance on groundwater for which a detailed study is recommended focusing on cost-benefit analysis of the proposal.

- Since the current study was limited to the Choa Saiden Shah area focused on drying out of the sacred pond, therefore, a future study is recommended for qualitative \& quantitative groundwater analysis of the whole Salt Range to delineate the negative and positive areas for future industrial development.

\section{ACKNOWLEDGMENTS}

The authors would like to acknowledge the cooperation of the Punjab Mines \& Minerals Department, Pakistan Metrological Department, Punjab Public Health Engineering Department, Punjab Saaf Pani Company, and Punjab Agriculture Department for the provision of relevant data. The funds incurred on the research were provided by the authors exclusively.

\section{DATA AVAILABILITY STATEMENT}

The data that support the findings of this study are available from the corresponding author upon reasonable request.

\section{REFERENCES}

Ahmad, M., Arshad, M., Iqbal, M., Waqas, M. M., \& Awais, M. (2017). Simulation of Groundwater Quantity using Hydrological Model for Mithawan Spate Irrigated Area of Dera Ghazi Khan, Pakistan. Pak. J. Agri. Sci, 54 (4), 847-853.

Ali, M. U. (2015). Temples of Katas: Their Historical and Religious Significiance. Yakın Doğu Üniversitesi Ilahiyat Fakültesi Dergisi, 1 (1), 49-63. 
Augustyn, A. (2020). Groundwater Recharge. Retrieved 10/04/2020, from https://www.britannica.com/science/groundwater-recharge

Batu, V. (1998). Aquifer hydraulics: a comprehensive guide to hydrogeologic data analysis : John Wiley \& Sons.

Bouwer, H. (2002). Artificial recharge of groundwater: hydrogeology and engineering. Hydrogeology journal, 10 (1), 121-142.

Dillon, P., Stuyfzand, P., Grischek, T., Lluria, M., Pyne, R., Jain, R., Fernandez, E. (2019). Sixty years of global progress in managed aquifer recharge. Hydrogeology journal, 27 (1), 1-30.

Famiglietti, J. S. (2014). The global groundwater crisis. Nature Climate Change, 4 (11), 945-948.

Ganesan, M. (2008). The temple tanks of Madras, India: rehabilitation of an ancient technique for multipurpose water storage. Indian journal of science and technology, 1 (7), 1-8.

Grau-Martínez, A., Folch, A., Torrentó, C., Valhondo, C., Barba, C., Domènech, C., Otero, N. (2018). Monitoring induced denitrification during managed aquifer recharge in an infiltration pond. Journal of Hydrology, $561,123-135$.

Harbaugh, A. W., Banta, E. R., Hill, M. C., \& McDonald, M. G. (2000). MODFLOW-2000, The U. S. Geological Survey Modular Ground-Water Model-User Guide to Modularization Concepts and the GroundWater Flow Process. Open-file Report. U. S. Geological Survey (92), 134.

Hariharan, V., \& Shankar, M. U. (2017). A review of visual MODFLOW applications in groundwater modelling. Paper presented at the IOP Conf. Ser. Mater. Sci. Eng.

Hashemi, H., Berndtsson, R., \& Persson, M. (2015). Artificial recharge by floodwater spreading estimated by water balances and groundwater modelling in arid Iran.Hydrological Sciences Journal, 60 (2), 336-350.

Hydrogeologic, W. (2015). Visual MODFLOW 2011.1 User's Manual: For Professional Applications in ThreeDimensional Groundwater Flow and Contaminant Transport Modeling. Waterloo Hydrogeologic Ink., Waterloo, ON, Canada .

Konikow, L. F. (2011). Contribution of global groundwater depletion since 1900 to sea-level rise. Geophysical research letters, 38 (17).

Kumar, C. (2002). Groundwater flow models. Scientist 'E1'National Institute of Hydrology Roorkee-247667 (Uttaranchal) publication .

Kumar, C. (2013). Numerical modelling of ground water flow using MODFLOW. Indian Journal of Science, $2(4), 86-92$.

Maidment, D. R. (1993).Handbook of hydrology (Vol. 9780070): McGraw-Hill New York.

McDonald, M. G., \& Harbaugh, A. W. (1988). A modular three-dimensional finite-difference ground-water flow model (Vol. 6): US Geological Survey Reston, VA.

Shahab, T. (2019). Katas Raj and the Holy Pond of Tears. Retrieved 01-06-2020, from https://dailytimes.com.pk/343711/katas-raj-and-the-holy-pond-of-tears/

Shakoor, A., Arshad, M., Ahmad, R., Khan, Z. M., Qamar, U., Farid, H. U., . . . Ahmad, F. (2018). Development of groundwater flow model (MODFLOW) to simulate the escalating groundwater pumping in the Punjab, Pakistan. Pakistan Journal of Agricultural Sciences, 55 (3), 635-644.

Sheng, Z., \& Zhao, X. (2015). Special issue on managed aquifer recharge: powerful management tool for meeting water resources challenges: American Society of Civil Engineers.

Subramanya, D. K. (2007).Engineering Hydrology (S. Mukherjee Ed. 3 ed. Vol. 1). New Dehli: Tata McGraw-Hill Publishing Company Limited. 
Wada, Y., Van Beek, L. P., Van Kempen, C. M., Reckman, J. W., Vasak, S., \& Bierkens, M. F. (2010). Global depletion of groundwater resources. Geophysical research letters, 37 (20).

Young, W. J., Anwar, A., Bhatti, T., Borgomeo, E., Davies, S., Garthwaite III, W. R.,Makin, I. (2019).Pakistan: Getting more from water: World Bank.
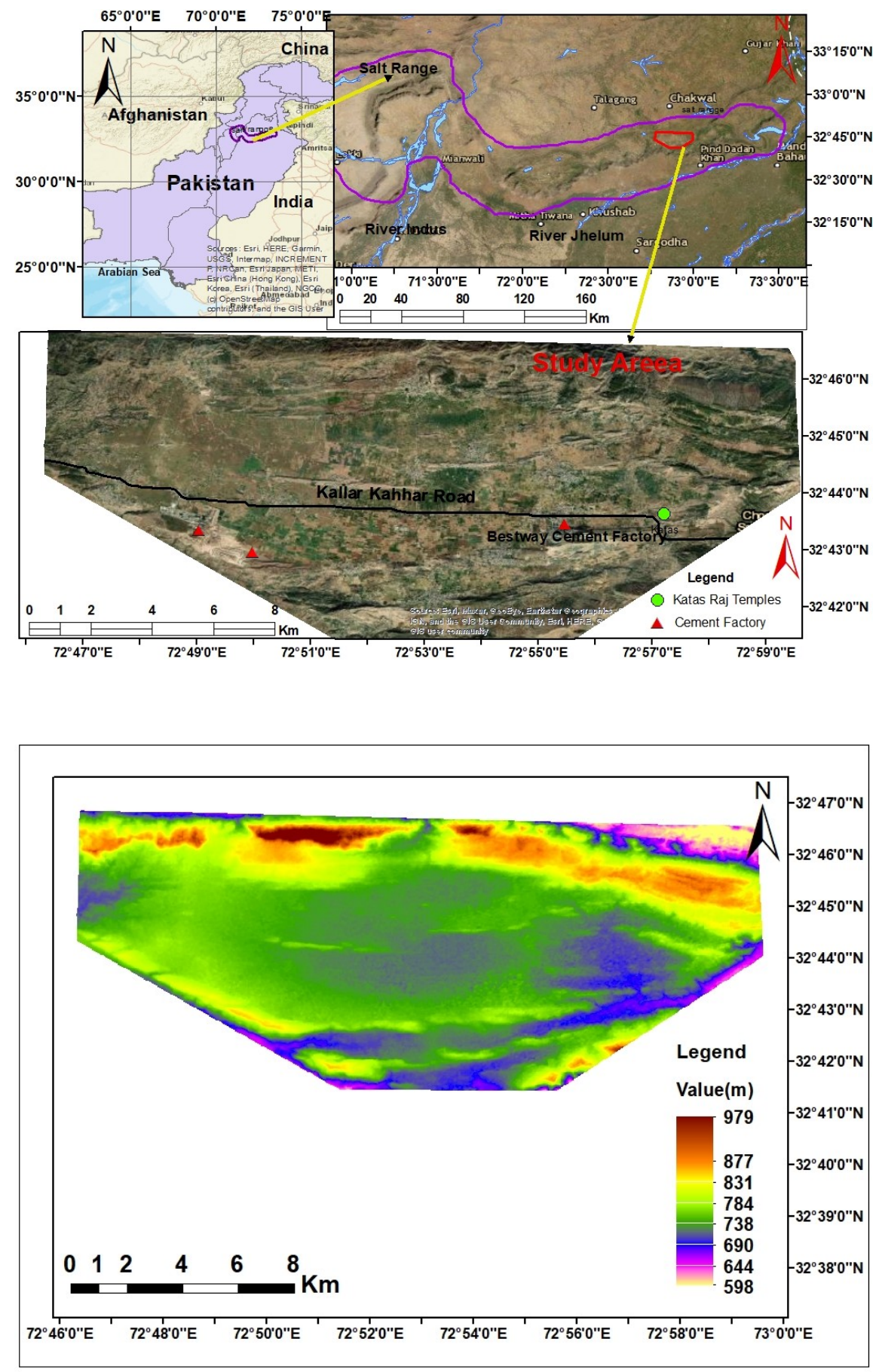

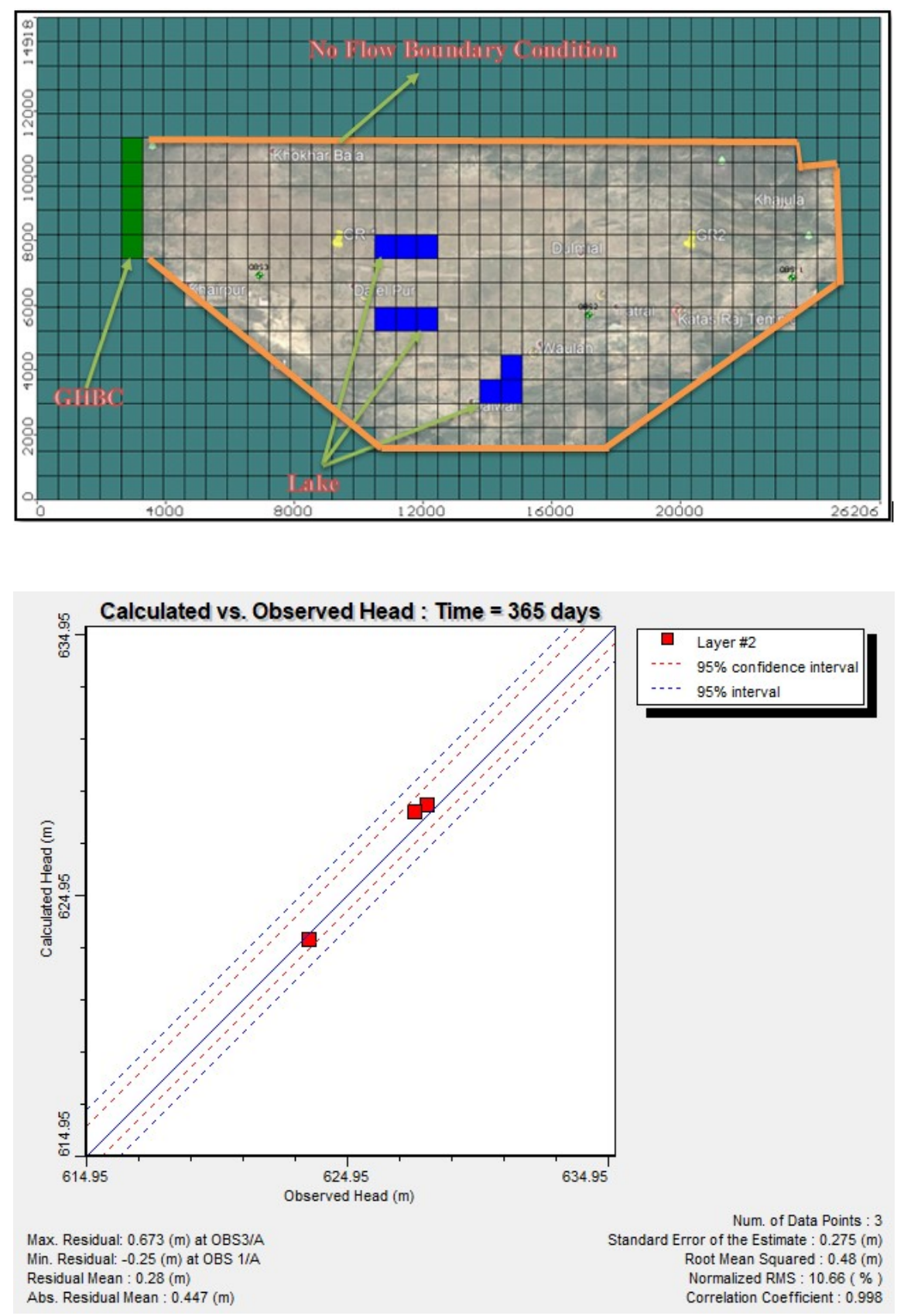

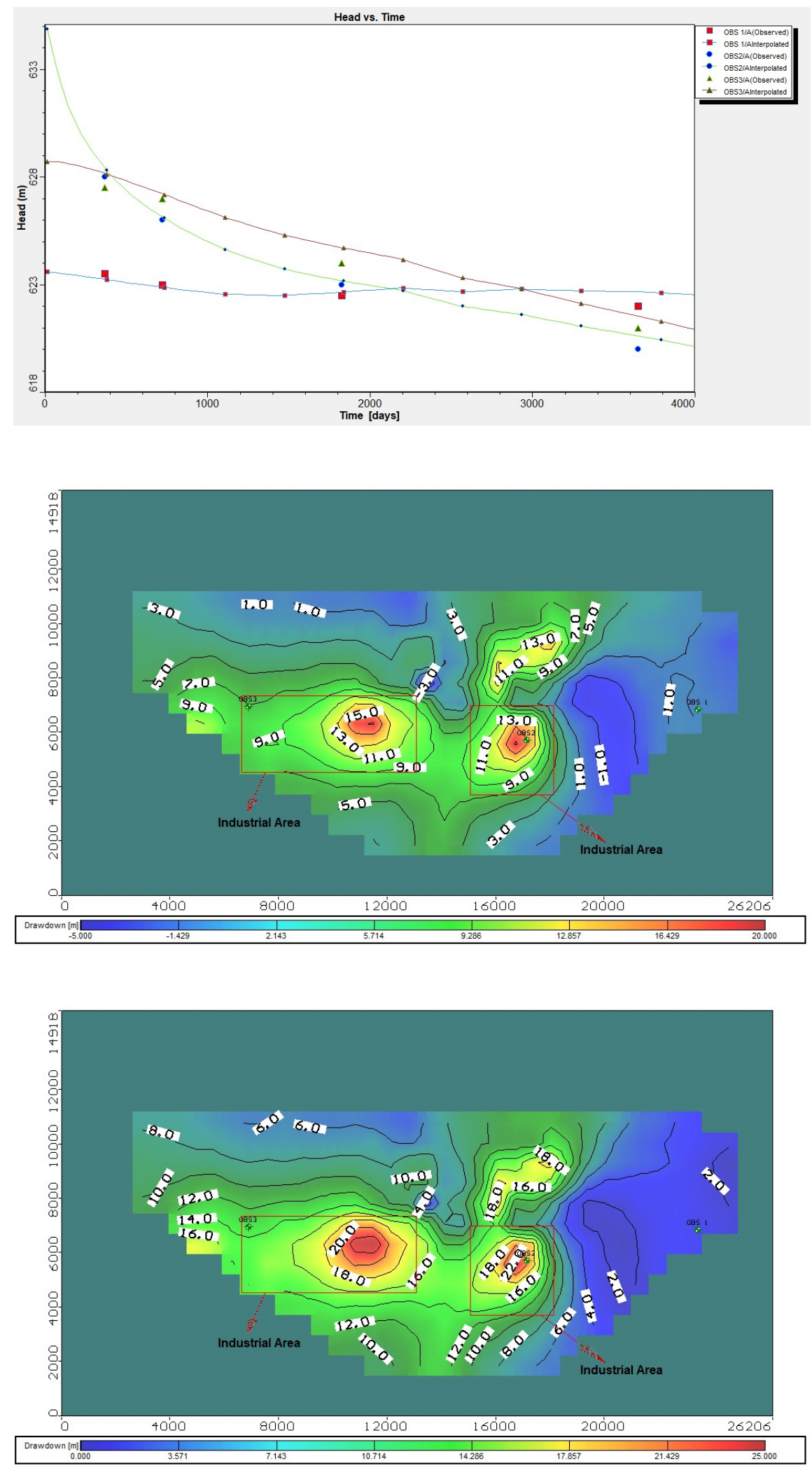

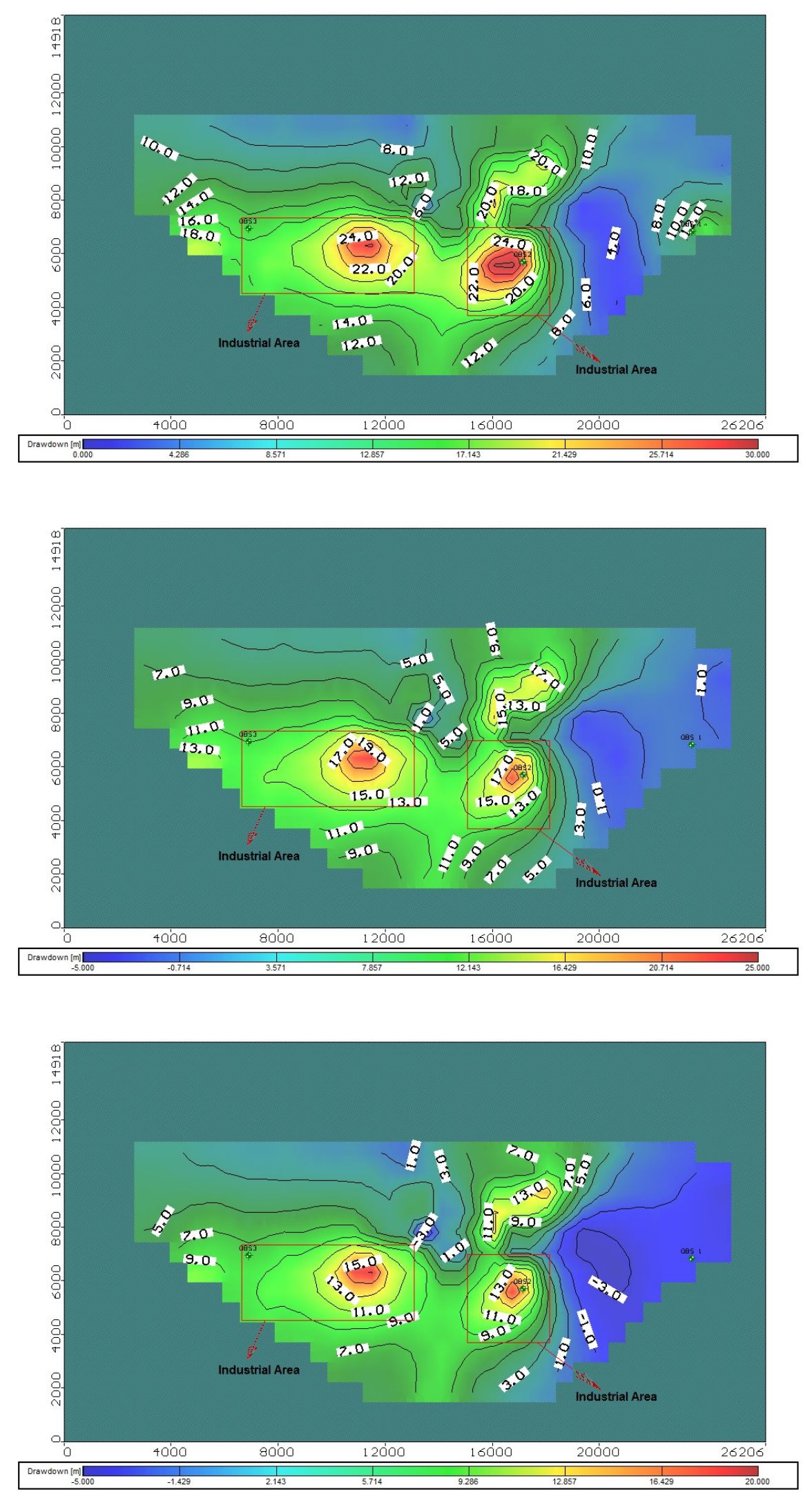

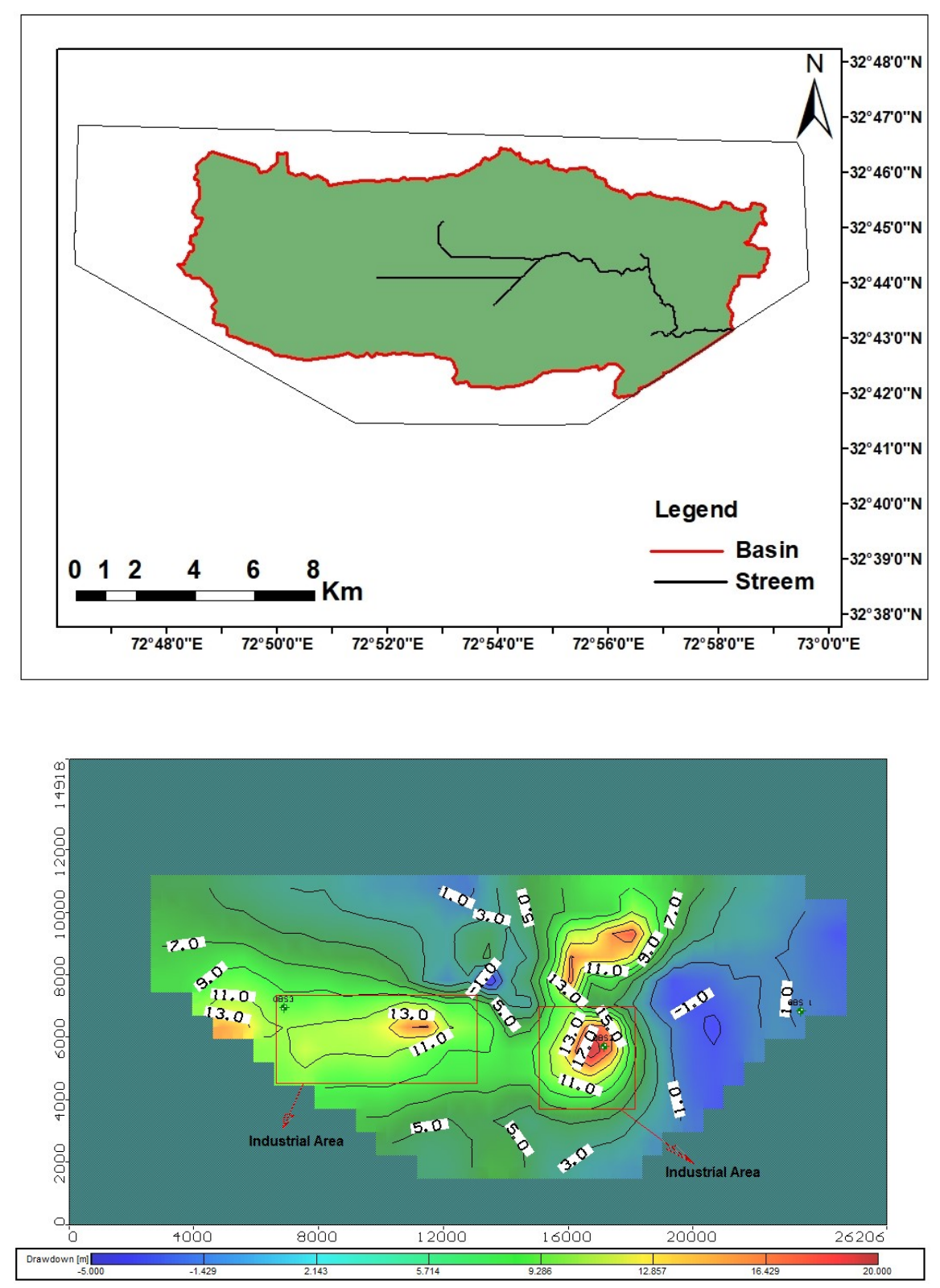

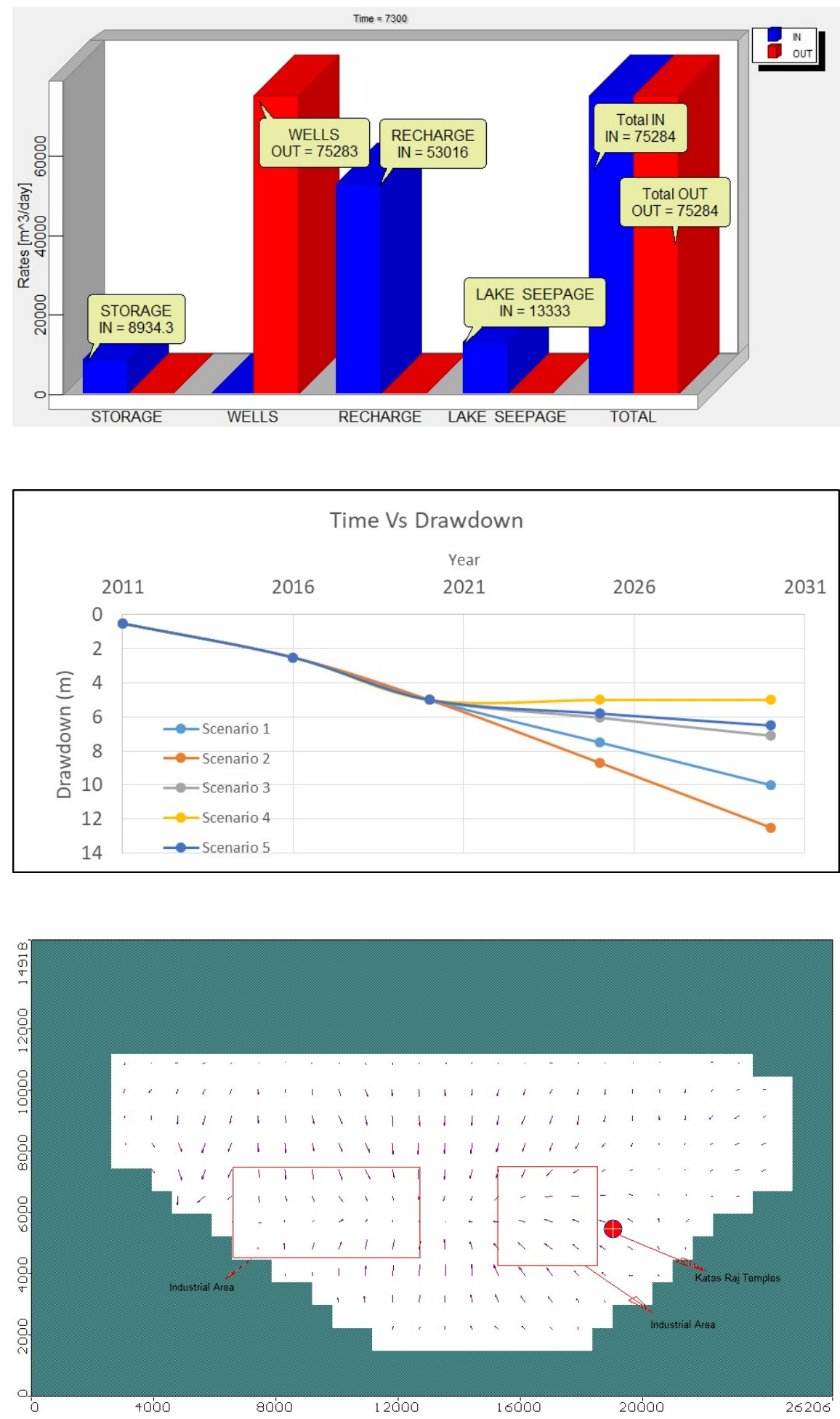

\section{Hosted file}

Table 1.xlsx available at https://authorea.com/users/362075/articles/483323-sustainablegroundwater-management-in-rolling-terrain-around-the-sacred-katas-raj-temples-salt- 
range-pakistan-under-climate-change-and-industrial-stress

\section{Hosted file}

Table 2.xlsx available at https://authorea.com/users/362075/articles/483323-sustainablegroundwater-management-in-rolling-terrain-around-the-sacred-katas-raj-temples-saltrange-pakistan-under-climate-change-and-industrial-stress 